To appear in the proceedings of the Symposium on Recent Developments in Engineering Science at the Society of Fingineering Science (SES) 32nd Annual Technical Meeting, New Orleans, October 29-Norember 1, 1995

\title{
Prediction of Damage Evolution in Continuous Fiber Metal Matrix Composites Subjected to Fatigue Loading
}

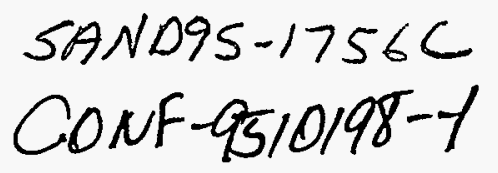

D. Allen 1, K Helms 1, L. Hurtador, and D. Lagoudas 1

1Center for Mechanics of Composites

Texas A\&M University

College Station, TX 77843-3141

2Sandia National Laboratories, New Mexico

P. O. Box 5800

Albuquerque, NM 87185

RECEIVED

AUG 171995

OSTI

\section{ABSTRACT}

A life prediction model is being developed by the authors for application to metal matrix composites (MMC's). The systems under study are continuous silicon carbide fibers imbedded in titanium matrix. The model utilizes a computationally based framework based on thermodynamics and continuum mechanics, and accounts for matrix inelasticity, damage evolution, and environmental degradation due to oxidation. The computational model utilizes the finite element method, and an evolutionary analysis of a unit cell is accomplished via a time stepping algorithm. The computational scheme accounts for damage growth such as fiber-matrix debonding, suiface cracking, and matrix cracking via the inclusion of cohesive zone elements in the unit cell. These elements are located based on experimental evidence also obtained by the authors.

The current paper outlines the formulation utilized by the authors to solve this problem, and recent results are discussed. Specifically, results are given for a four-ply unidirectional composite subjected to cyclic fatigue loading at $650^{\circ} \mathrm{C}$ both in air and inert gas. The effects of oxidation on the life of the composite are predicted with the model, and the results are compared to limited experimental results.

\section{INTRODUCTION}

Over the last three decades metal matrix composites (MMC's) have received increased emphasis as potential materials in a variety of advanced technological applications. These include the National AeroSpace Plane (NASP), Integrated High Performance Turbine Engine Technology (IHPTET), and the High Speed Civil Transport (HSCT) $[1,2]$. A primary motivation for 


\section{DISCLAIMER}

Portions of this document may be illegible in electronic image products. Images are produced from the best available original document. 
utilizing these materials is that they have potentially improved performance at elevated temperatures as compared to either monolithic metals or polymer matrix composites. Unfortunately, while the concept appears to be viable, continuous fiber MMC's have found only limited applications due to a variety of shortcomings that generally lead to low fracture toughness and limited life [3]. These limitations have received considerable attention by the research community, but solutions have yet to be fully achieved.

Due to their promising potential, MMC's have received a substantial amount of experimental investigation. One significant area of interest has been that of the processing-induced thermal residual stresses inherent to MMC's [4-10]. As many proposed MMC applications include cyclic mechanical loading histories, a second primary research concern has been that of characterizing fatigue and identifying fatigue damage mechanisms in MMC's [11-19]. A third focus of MMC research has been driven by the elevated service temperatures anticipated for MMC applications. To obtain a more thorough understanding of MMC behavior under thermal fatigue and mechanical fatigue at elevated temperatures, several experimental studies have been undertaken [20-23]. In addition, experimental efforts have also been devoted to the case of combined cyclic mechanical and thermal loading histories, i.e. thermomechanical fatigue (TMF) of MMC's [24,25].

Unfortunately, the experiments required to completely characterize MMC's especially at elevated temperatures are extremely costly. Consequently, a great deal of general MMC research has dealt with improved modeling of MMC's. To effectively model MMC behavior, several factors have been scrutinized including: 1) the effects of thermal gradients $[26,10]$. 2) the effects of fiber and interfacial layer morphologies [27]. 3) the type of reinforcement used, especially long brittle fibers $[28,29]$.

By incorporating the most significant factors thus far. investigated, attempts have been made to predict damage evolution and life. Using differential Continuum Damage Mechanics (CDM) models, fatigue-induced damage evolution has been predicted in $M M M^{\prime}$ 's [30-32]. Oxidation of MMC's and subsequent oxidation-induced damage have also been modeled with success [33-35]. In an attempt to predict titanium MMC behavior, fatigue maps have been developed which identify expected damage mechanismis for varying loading conditions [36]. Unfortunately, all MMC research efforts thus far have resulted in only a limited number of life prediction models for MMC's, in general. One of these models incorporates an effective properties micromechanics scheme [37]. Another model incorporates a unit cell micromechanics approach which includes the effects of a viscoplastic matrix and damage accumulation [38]. Two other life prediction models appropriate for thermomechanical fatigue have been suggested: one which provides a basic modeling framework [39], and one which utilizes an effective properties micromechanics approach [A0]. Additionally, to aid in life prediction, several computer codes have been developed to predict inelastic fatigue response of MMC's. Kroupa and co-workers have recently completed a full review of these codes [41]. 
One of the primary focuses of MMC research has been the characterization . and experimentation with titanium matrix systems. Titanium systems have been pursued due to many advantageous qualities: high specific strength, high temperature strength, potential for ductility in manufacturing processes, and potential for limited detrimental environmental effects. A comprehensive summary of many researchers' efforts of the past four years in titanium metal matrix composites has recently been compiled [42]. Additionally, several individual material systems, utilizing various titanium alloys for the matrix component, have been investigated for environmental, fatigue, and elevated temperature behavior [43-51]. Two particular matrix candidates, however, have received the most interest as of late for high temperature applications: Ti-15-3 and Titanium B21-S. Both alloys are of the metastable beta titanium class.

One system which utilizes the first alloy mentioned above, SiC/Ti-15-3, has received a great deal of investigation. Many of the previously identified key areas of MMC research have been pursued for this system: fatigue behavior, damage mechanisms, and elevated temperature behavior [52-58]. Unfortunately, this system has been found experimentally to be severely affected by an oxygen environment. Recent modeling efforts have successfully predicted this shartcoming $[59,60]$.

The second alloy also with silicon carbide reinforcement, SiC/Titanium B21$S$, has quichly become the most favored titanium system due to its improved oxidative performance over Ti-15-3. Fortunately, this second titanium alloy has received a great deal of research interest which has provided a good base for understanding the MMC behavior. First, complete material property information has been published for a commercially available ß21-S alloy manufactured by TIMET, TIMETAL $\otimes 21-S[61,62]$. Second; for use in the viscoplastic constitutive modeling of this alloy, the Bodner-Partom model coefficients have been determined [63]. Third, extensive study of the oxidative and corrosive behavior of this alloy has also been completed [64-71]. Fourth, research efforts have been undertaken to completely characterize the material properties of various SiC/Titanium B21-S material systems [72-74]. Finally, many experimental investigations of fatigue behavior and damage mechanisms have been completed to enlarge the understanding of this material system behavior [75-80]. TMF behavior has also been investigated via acoustic techniques [81].

In addition to experimental investigation of B21-S systems, several models have been proposed for predicting their TMF behavior and life. Micromechanics approaches have been suggested by several researchers for both compressive behavior and fatigue behavior of both unidirectional and crossmply composites [82-85]. Another approach has been to utilize a linear life fraction approach $[86,87]$. A third modeling method tried has been to use a uniarial stress model, which also uses a viscoplastic constitutive model for the matrix [88]. The most recent model which has been proposed for predicting damage mechanism maps incorporates a uniaxial stress model, in conjunction with a viscoplastic constitutive model for the matrix [89]. 


\section{PROBLEM SOLUTION SCHEME}

The primary emphasis of the current paper is to develop a model that is capable of predicting the effect of oxidation on the life of a typical continuous fiber MMC. The intent of this model is to develop the capability in such a way that at least some experiments can be obviated, thereby decreasing material development costs due to the extremely expensive process of developing experimental life curves for SiC/Ti MMC's. More importantly, it is hoped that a model of the type discussed herein will give insight into ways of developing new MIMC systems that have improved life in an oxidative environment.

Although there have been previous efforts to develop oxidation dependent life models [40], the model discussed herein takes a different approach. Specifically, the current effort uses a diffusion model based on conservation of mass to predict the development of an oxide layer on the surface of the composite $[59,33]$. This growing phase is embrittled, so that surface cracks form and shed load to the interior of the composite, thereby accelerating the development of other damage and significantly curtailing the life of the composite.

\subsection{Formulation}

(a) Thermomechanical Model

The analysis of the metal matrix composite is accomplished by satisfying the conservation of linear momentum:

$$
\sigma_{i j}=0
$$

where $\sigma_{\tilde{j}}=\sigma_{\bar{j}}\left(x_{k}, t\right)$ is the stress tensor, and body forces and inertial terms are neglected. Furthermore, angular momentum is trivially satisfied by the assumption that the stress tensor is symmetric. The above equation is adjoined with strain-displacement equations:

$$
\varepsilon_{\bar{j}}=\frac{1}{2}\left(u_{i j}+u_{j i}\right)
$$

where $u_{i}=u_{i}\left(z_{k}, t\right)$ is the displacement field, and $\varepsilon_{j}=\varepsilon_{i j}\left(x_{k}, t\right)$ is the strain tensor for infinitesimal displacements. Finally, the thermomechanical constitutive equations are given by:

$$
\sigma_{i}=D_{i j d}\left(\varepsilon_{y}-\varepsilon_{\mathrm{y}}^{\mathrm{X}}-\varepsilon_{\mathrm{H}}^{\mathrm{I}}-\varepsilon_{\mathrm{d}}^{\mathrm{T}}\right)
$$

where $D_{i j k l}$ is the elastic modulus tensor, $\varepsilon_{\mathrm{y}}^{\mathrm{k}}$ is the phase change eigenstrain to be described below, $\varepsilon_{\mathrm{k}}^{\mathrm{I}}$ is the inelastic strain tensor, and $\varepsilon_{\mathrm{kd}}^{\top}$ is the thermal 
strain tensor. The thermal strain tensor is assumed to be a function of the temperature, which is obtained from a solution of the conservation of energy, which is assumed to be uncoupled in the current model [90]. The inelastic strain tensor, and additional internal variables, are assumed to be governed by internal variable evolution laws of the form:

$$
\alpha_{\tilde{i}}^{\prime \prime}=\Omega_{i \mathfrak{j}}^{\eta}\left(\varepsilon_{k 1}, \varepsilon_{k l}^{l}, T, \alpha_{k 1}^{\mu}\right) \quad \eta=1, \ldots, n ; \mu=1, \ldots, \pi
$$

where $\mathrm{n}$ is the number of internal variables. In the current research the socalled anisatropic Bodner model is utilized [91]. This model has been selected not only because it has been shown to be accurate for titanium [63], but also because the material parameters do not appear to be available for other models.

In the current paper, the fiber is assumed to be thermoelastic $\left(\varepsilon_{i j}^{\prime} \equiv 0\right)$. Assuming that the temperature field is known (from conservation of energy), the above field equations can be cast with appropriate mechanical boundary conditions to produce a well-posed boundary value problem.

The thermomechanical model proceeds from the application of continuum thermomechanics to a thermoviscoplastic medium [90]. Due to the nonlinearities introduced by the thermoviscoplastic constitutive model, analytic solutions are not practical for most geometries and loading conditions. Therefore, the solutions are obtained computationally via the finite element method.

The details of the formulation are given in Allen, et al. [38] and Jeong, et al. [10]. Briefly, the conservation of momentum (1) is cast into a weak variational principle in terms of the primary variable $u_{i}=u_{i}\left(x_{k}, t\right)$. This variational principle is incremented in time, and the strain-displacement equation (2) and constitutive equations (3) are substituted to obtain a field problem which can be discretized for a typical finite element. Due to the fact that internal variable evolution equations (4) are ordinary differential equations, the variational principle must be incremented in time, and the solution is obtained by incrementing the boundary data with time. Due to the nonlinearity of evolution equations (4) (they are actually numerically stiff), extremely small time steps are required in order to obtain accurate solutions, so that for cyclic loading the solution is computationally intensive. As described in the section on crack growth, this problem may be exacerbated by instabilities introduced during periods of crack propagation.

\section{(b) Oxidation Model}

The oxidation model proceeds from the assumption that the mass of oxygen is conserved within the solid MMC. This produces a diffusion model for the species of oxygen, $c=c\left(x_{k}, t\right)$, of the form: 


$$
\left(D c_{j}\right)_{j}=\frac{\partial c}{\partial t}
$$

where $D$ is the diffusivity of oxygen within a particular media, and $t$ denotes time dependence. The solution of this equation is complicated by the assumption that when the oxygen concentration reaches a critical value, $c_{c r}$, there is an instantaneous phase change from titanium alloy to rutile $\mathrm{TiO}_{2}$. This then produces a moving interface in the interior of the matrix, and this interface is assumed to have a jump condition of the form:

$$
c_{\mathrm{Int}}=\lim _{x \rightarrow x_{10}} c_{2}-\lim _{x \rightarrow x_{1 \mathrm{~lx}}} c_{1}
$$

in order to account for the observation that oxygen is trapped in the interface layer. The authors have studied the oxidation problem in some detail [3335,59-60]. Various geometries have been considered for one dimensional diffusion. For example, typical results for both a plane surface and for a cylinder with $c=$ constant imposed on the interface surface are shown in Fig. 1.

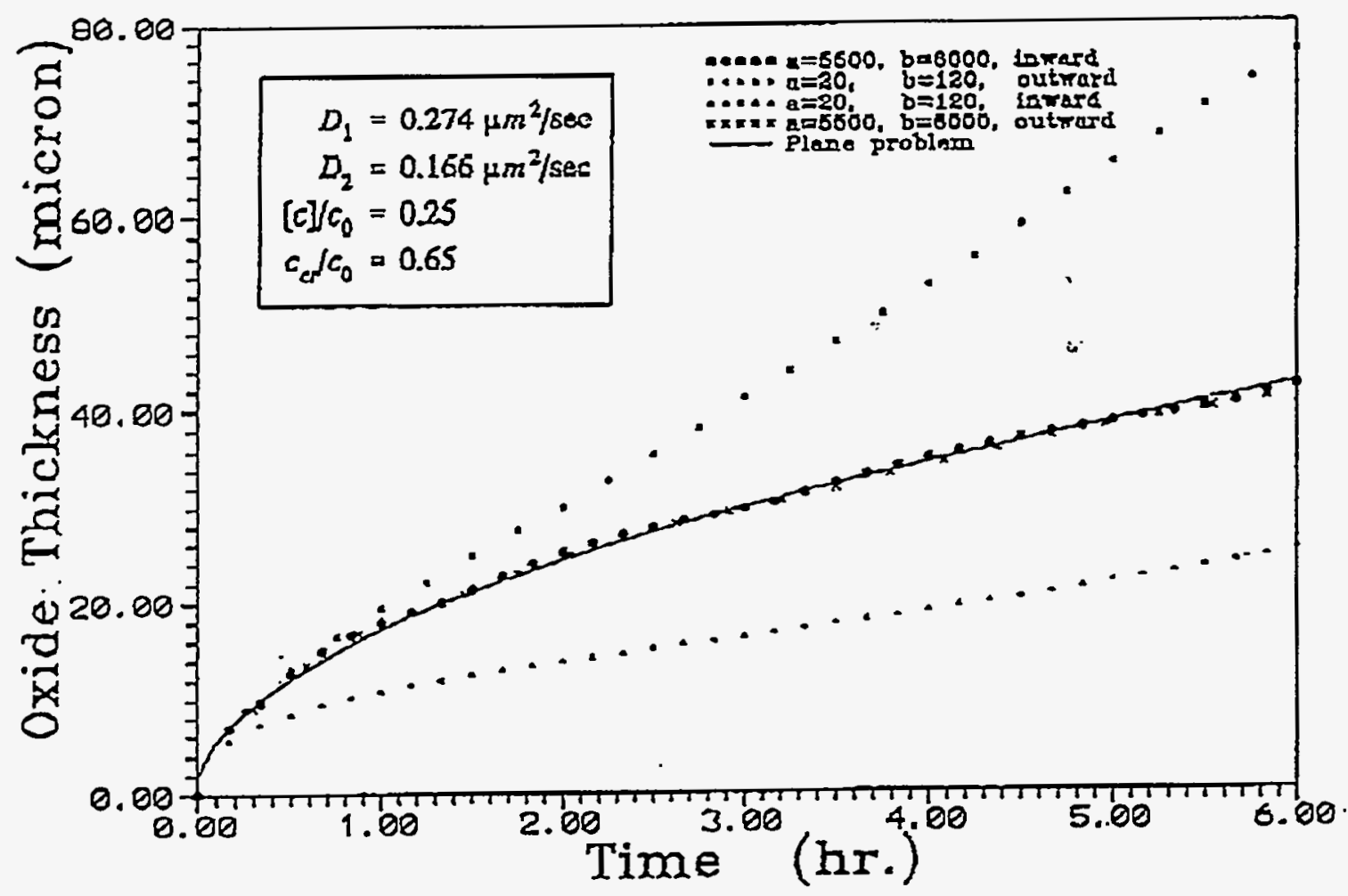

Figure 1. Oxide thickness vs. time for various geometries with constant c, where $a$ is the radius of the inner surface and $b$ is the radius of the outer surface in microns for the cylindrical geometry. 
The figure shows the growth of the oxide thickness with time. Both the inward and outward diffusion cases are considered for the cylindrical problem, where inward diffusion occurs in the direction of the inward normal to the cylindrical interface surface and outward diffusion occurs in the direction of the outward normal to the cylindrical interface surface. This model is utilized to predict the evolution of the oxide layer on the surface of the composite. Any material that has oxidized is assumed to have undergone a phase-change induced dilatational eigenstrain of:

$$
\varepsilon_{\mathrm{i}}^{\mathrm{PC}}=\mathrm{d} \delta_{\mathrm{j}}
$$

where $\delta_{\bar{j}}$ is the Kroneker deita, and $a=0.001$, based on experimental data [92]. It is thus apparent that surface oxidation drives the surface layer into compression in the absence of far-field loads.

(c) Crack Growth Model

The evolution of damage in the unit cell is accomplished by implementing cohesive zone elements into the finite element algorithm. This procedure is not only numerically efficient, it is also physically attractive. The cohesive zone model utilizes a non-convex quasi-potential to produce a smooth transition from displacement continuity along predetermined internal surfaces to traction-free internal boundaries, thereby effecting crack growth. This procedure has been utilized recently by several researchers $[93-95,38]$ to successfully model the evolution of damage in metals and MMC's. Most recently, Allen and coworkers [96,97] have used this procedure to model interactions between multiple damage modes.

In the current paper, one of the models developed by Tvergaard [94] is used. The cohesive zone model proceeds from the definition of a quasi-potential:

$$
\Phi\left(u_{x}, u_{t}\right) \equiv \int_{0}^{\lambda} F\left(\lambda^{\prime}\right) d \lambda .
$$

where

$$
F(\lambda) \equiv \frac{D}{4} \sigma_{\text {axa }}\left(\lambda-2 \lambda^{2}+\lambda^{3}\right)
$$

and

$$
\lambda \equiv\left[\left(u_{n} / \delta_{n}\right)^{2}+\left(u_{t} / \delta_{i}\right)^{2}\right]
$$

where $u_{n}$ and $u_{t}$ are the normal and tangential components of crack opening displacement in the cohesive zone, as shown in Fig. 2. Furthermore, the function $F(\lambda)$ is graphically depicted in Fig. 3 , wherein the material parameter 
$\mathbf{n}$

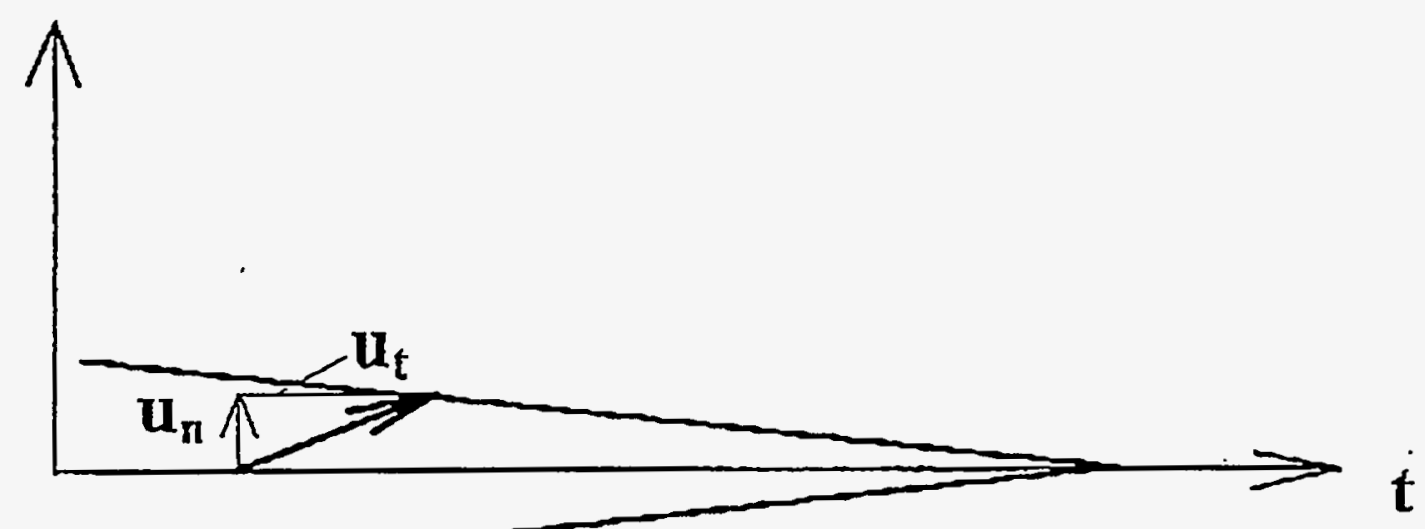

Figure 2. Normal and Tangential Components of the Crack Opening Displacement in the Cohesive Zone

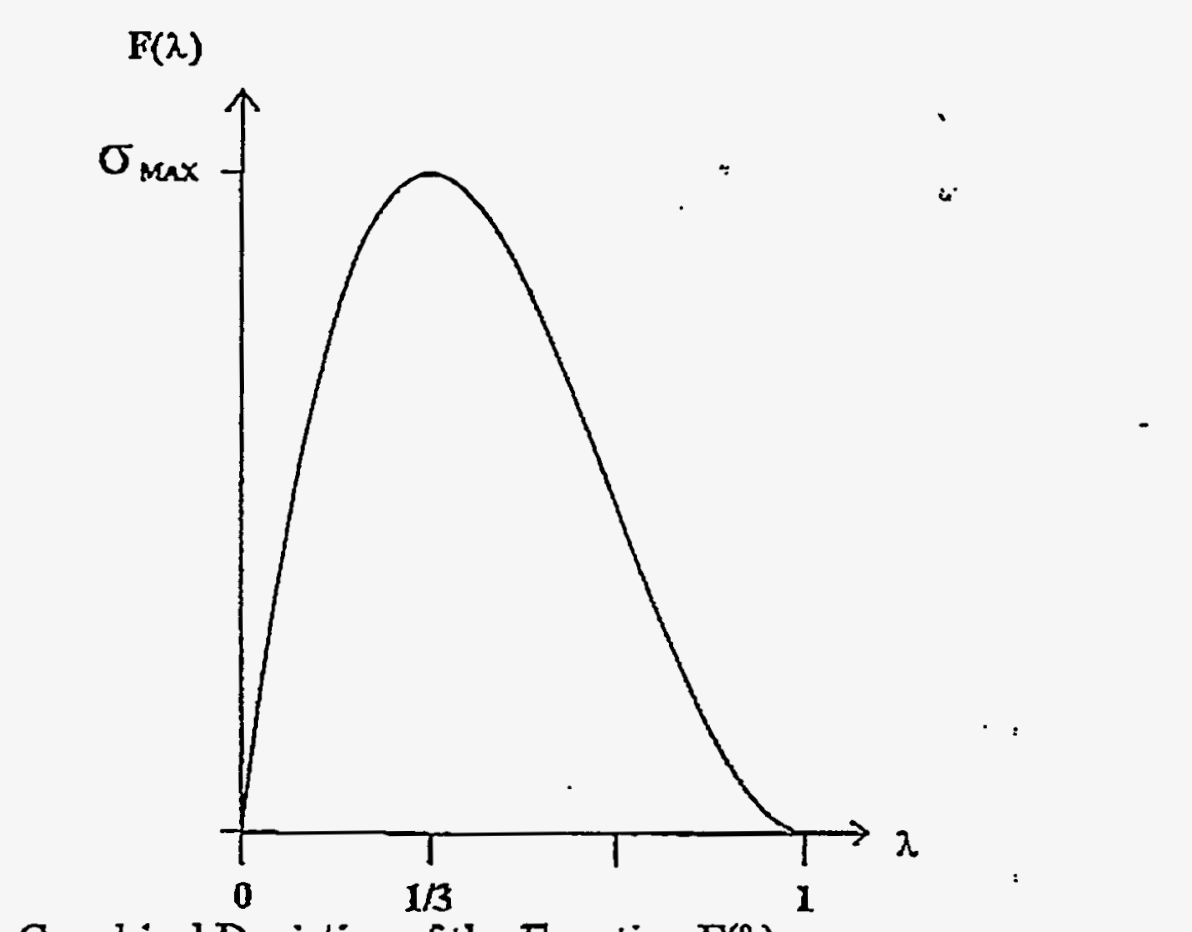

Figure 3. Graphical Depiction of the Function $F(\lambda)$ 
$\sigma_{\text {max }}$, is depicted. In addition, $\delta_{n}$ and $\delta_{t}$ are material parameters. The resulting normal and tangential components of the tractions along the cohesive zone are:

$$
T_{n}=\frac{\partial \Phi}{\partial u_{n}}=\frac{F(\lambda)}{\lambda} \frac{u_{n}}{\delta_{n}}
$$

and

$$
T_{1}=\alpha \frac{\partial \Phi}{\partial u_{t}}=\alpha \frac{F(\lambda)}{\lambda} \frac{u_{t}}{\delta_{t}}
$$

respectively, where $\alpha$ is the final material property for the cohesive zone model.

The cohesive zone model description is completed by the following constraints:

$$
\mathrm{T}_{\mathrm{n}}<0 \Rightarrow \mathrm{T}_{\mathrm{a}}=\mathrm{F}(0) \mathrm{u}_{\mathrm{a}} / \delta_{\mathrm{a}}
$$

and

$$
\lambda \geq 1 \Rightarrow \Upsilon_{n}=0
$$

The above formulation has been shown to produce a framework that is consistent with the notion of an energy release rate that is critical for crack growth $[98,99]$. This model has been implemented in the computational model used in this paper, so that the algorithm may be utilized to predict crack growth wherever interface elements are placed in the finite element mesh.

\section{RECENT RESEARCH}

\subsection{Experimental Results}

Cyclic fatigue tests have been performed by the authors and coworkers on a SCS-6/Tiß21S four ply unidirectional laminate (manufactured by Textron) loaded in the direction parallel to the longitudinal axis of the fibers. The data are extremely limited due to the cost and limited supply of the materials. The test in air was performed in our own labs, whereas the test in inert gas (Argon) was performed by Golam Newaz at Battelle Labs (now at Wayne 
State University). Both specimens came from the same plate. As shown in Fig. 4, the life of this composite at $650^{\circ} \mathrm{C}$ and a stress amplitude of $1,000 \mathrm{MPa}$ $(R=0.1)$ is reduced by about a factor of two thirds when the material is tested in air, as compared to when the material is tested in an inert gas (Argon). This is inspite of the fact that the Ti $\beta 21 \mathrm{~S}$ alloy is highly resistant to oxidation. Subsequent destructive examination of the specimen tested in air showed that both fiber-matrix debonding and radial cracking from the fiber into the matrix occurred during the test, as shown in Fig. 5. In addition, surface cracks appeared along planes normal to the loading direction, as demonstrated in Fig. 6. No ather microcracks were observed in the post-mortem inspection. These results were used as a guide to determine where the cohesive zone elements should be placed in the analysis described below. As shown in Fig. 7 , the peak average strain in the composite increases with each cycle, which nay indicate that the ultimate failure of the composite is driven by the peak strain in the fibers.

Oxidation results have also recently been obtained [100], but in this case the experiments were performed on SiC(sigma)/Ti-15-3 four ply unidirectional laminate. As shown in Fig. 8, the oxidation model compares quite favorably to the experimental results for the interface location as a function of time. Further results of this nature are available in references [33-35].

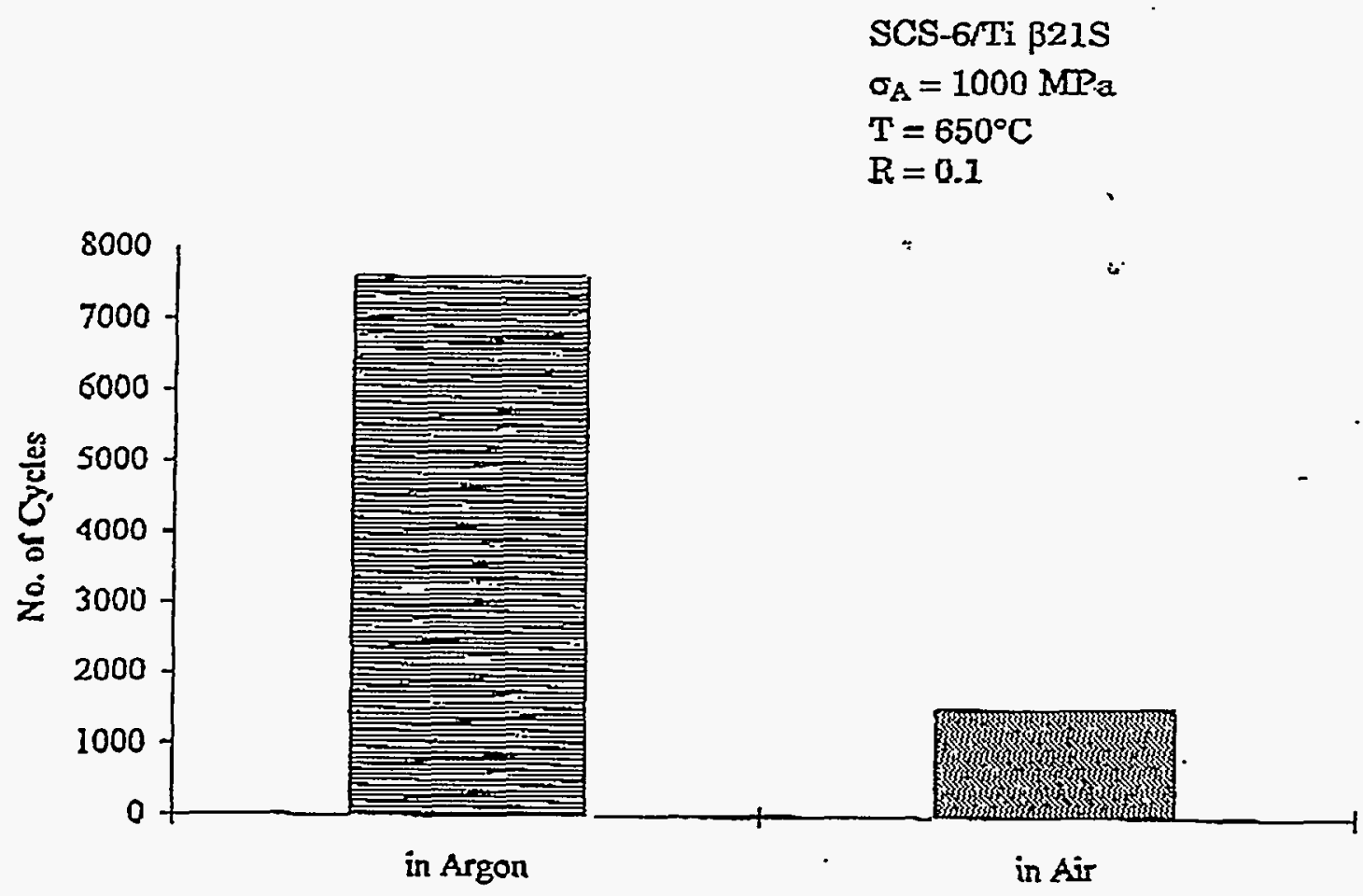

Figure 4. Composite Life in Argon vs. Air Environments 


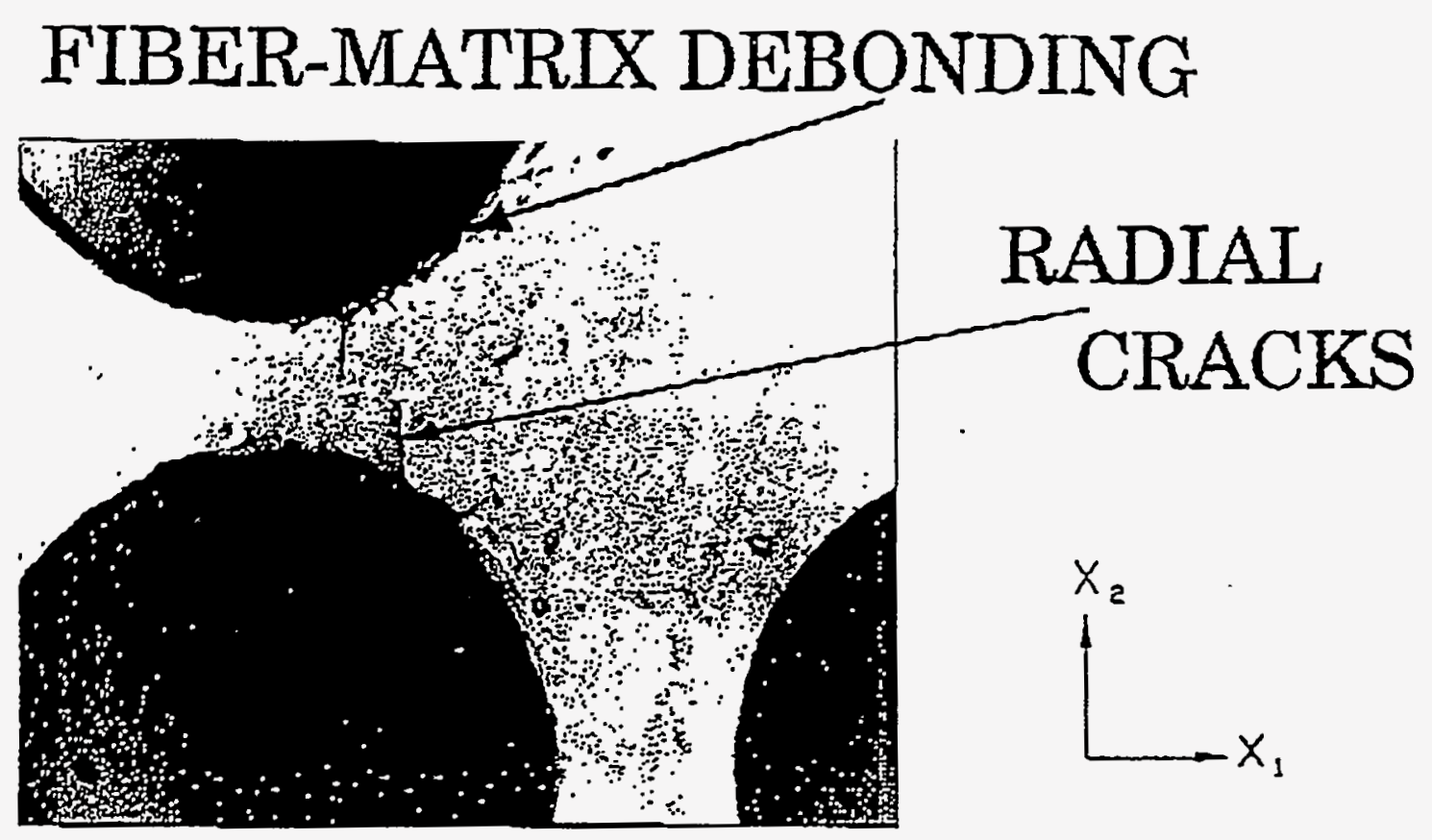

Figure 5. Optical photograph of fatigued specimen at $482^{\circ} \mathrm{C}$ (in Air), where the plane of view is normal to the loading direction, $X_{3}$

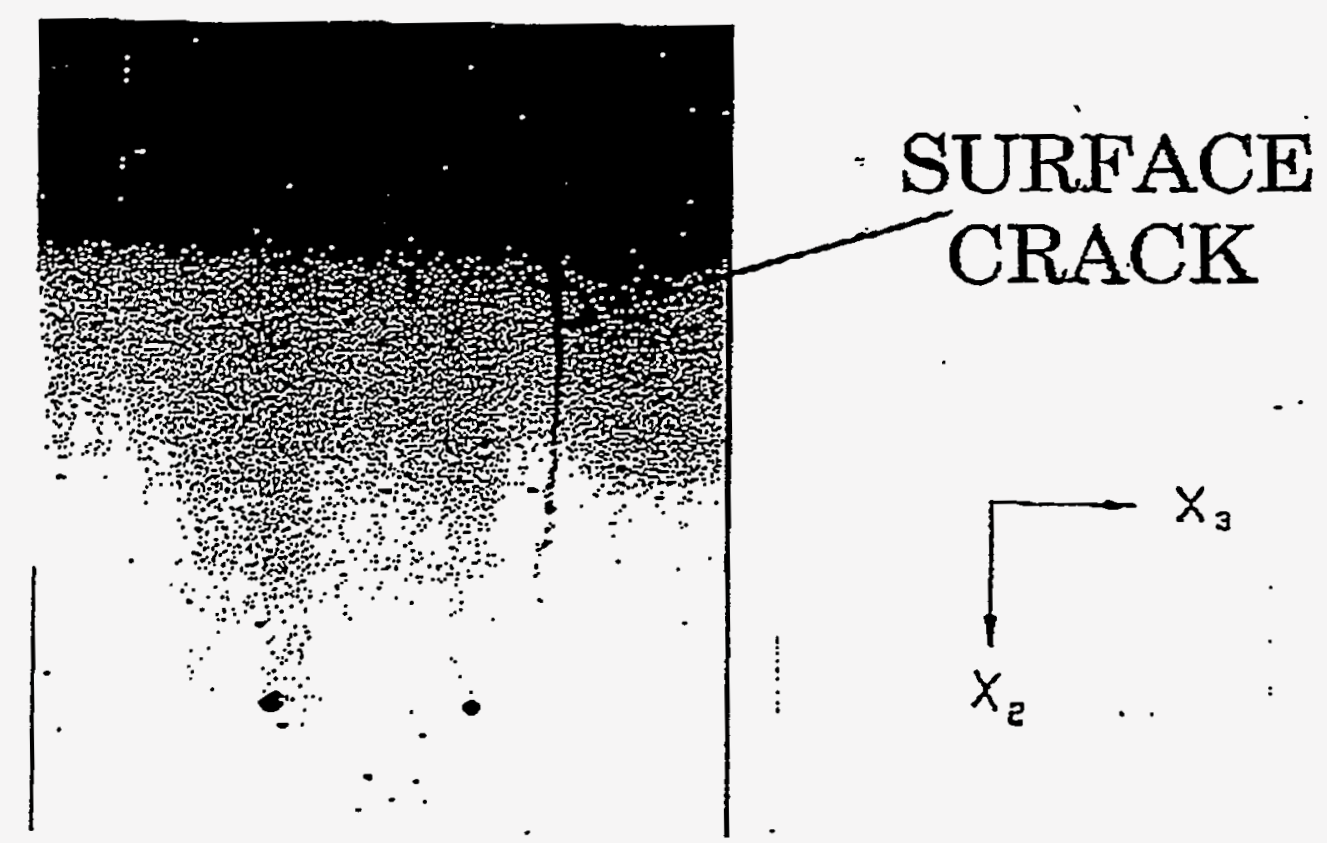

Figure 6. Optical photograph of fatigued specimen at $650^{\circ} \mathrm{C}$ (in Argon), where the surface transverse to the loading direction, $X_{3}$, is shown 


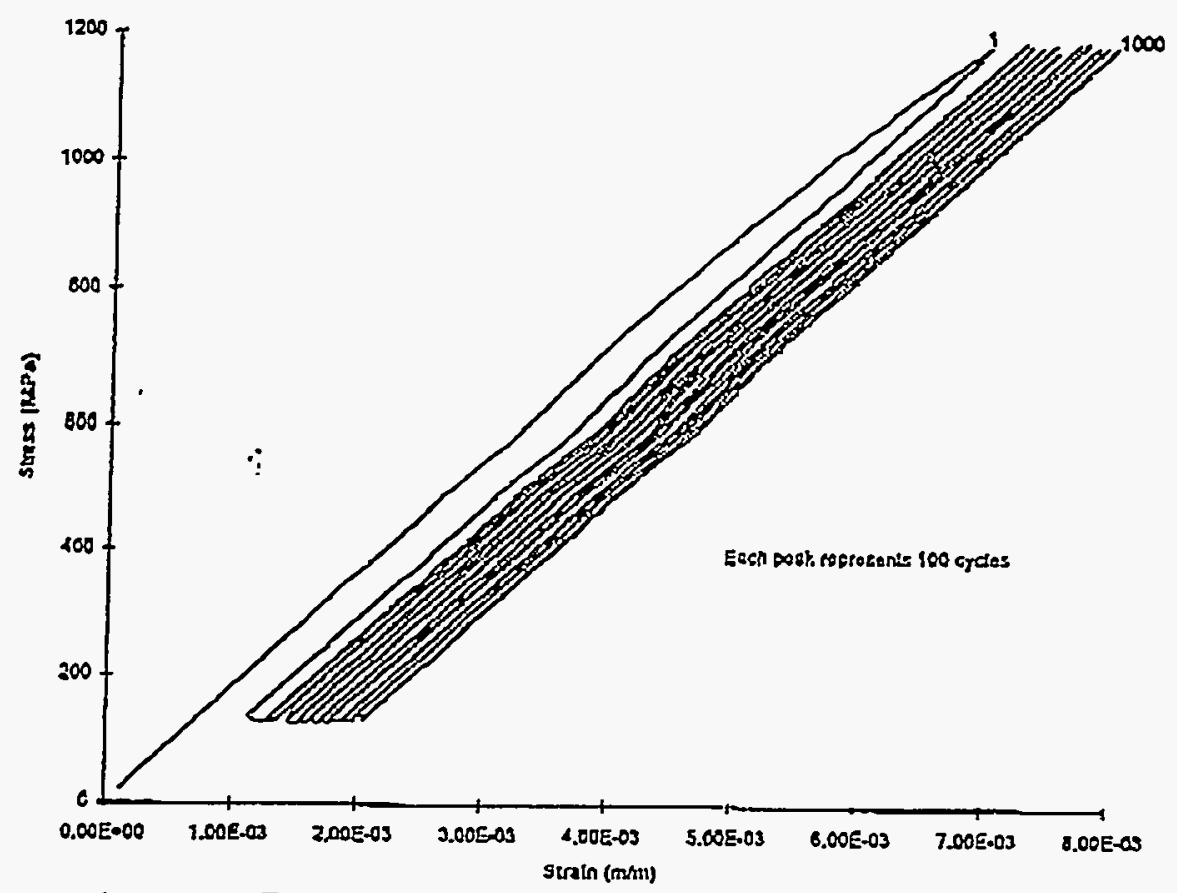

Figure 7. Average Stress vs. Strain for Cyclic Loading at $482^{\circ} \mathrm{C}$ (in Air)

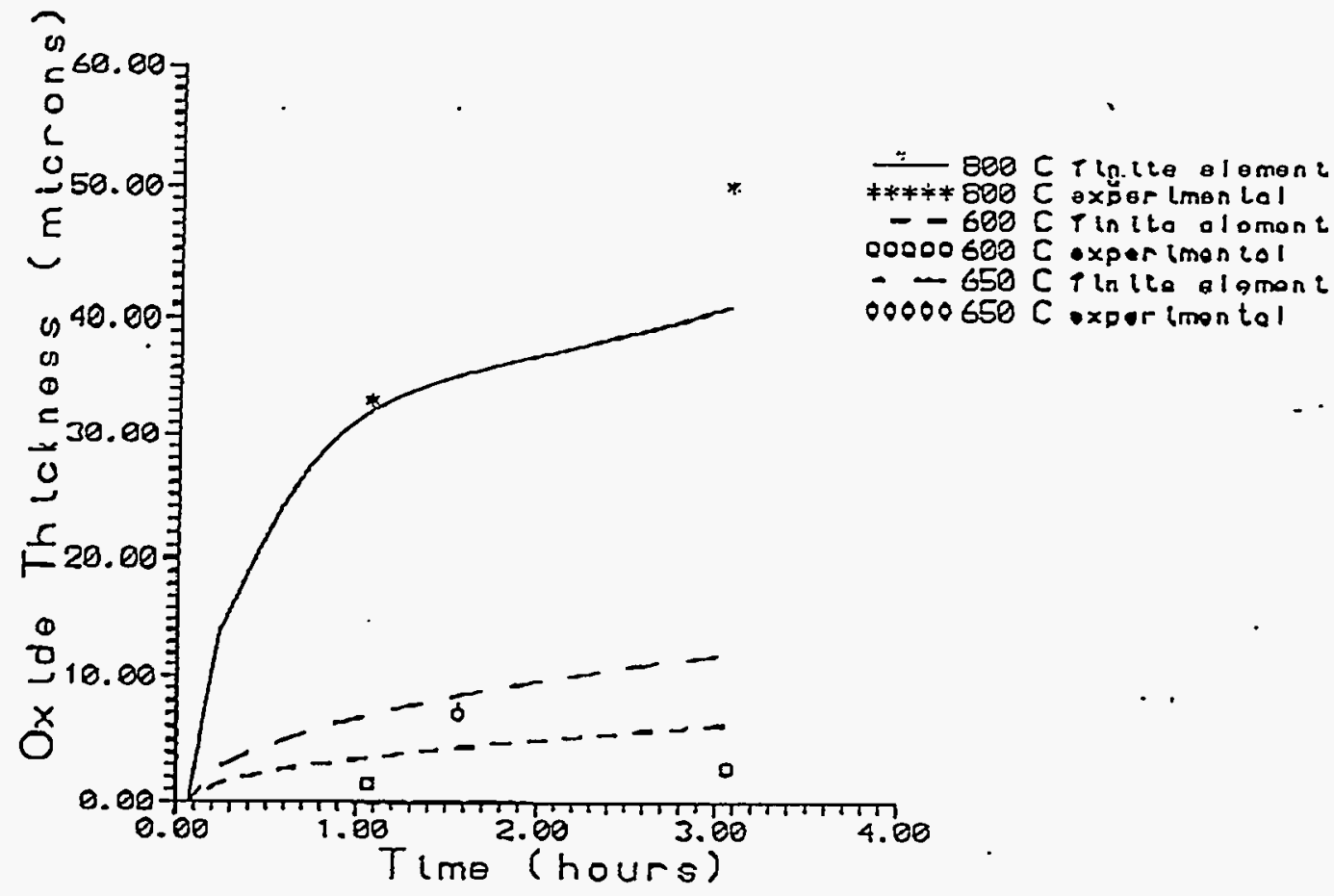

Figure 8. Comparison of Oxidation Model to Experiment 


\subsection{Thermomechanical Analyses}

The computational algorithm described above has been utilized to predict the effects of a variety of phenomena. For example, the effects of spatial and timewise temperature variations have been studied [10], and it has been determined that rapid cooldown during processing can have a deleterious effect on the interface stresses, thus hastening interface debonding and radial cracking on subsequent loading. The effect of interface debond strength on composite performance has also been studied [38], and it has been found that debonding can be delayed by increasing the interface bond strength, but not by substantial amounts. Interaction between various dissipation phenomena has been studied [96], and it has been demonstrated that an accurate prediction of the interaction between damage modes is essential in order to predict life of the specimen.

Recently, we have been able to obtain predictions for the response of a four ply unidirectional SCS6/Tiß21S coupon subjected to axial cyclic fatigue. As shown in Fig. 9, a unit cell has been used to perform a generalized plane strain cyclic analysis, and interface elements have been placed along the fibermatrix interface. A comparison of the model predictions to experimental data for the unoxidized experiment is shown in Fig. 10. Although it is seen that the predicted initial elastic stiffness does not agree with the experimental results (and we are not sure why), the trend toward increasing peak strain with cycle is at least qualitatively captured by the analysis. Our next plan will, therefore, be to continue the analysis, including cohesive elements to account for radial cracks, and use an allowable pealk fiber strain to predict life.
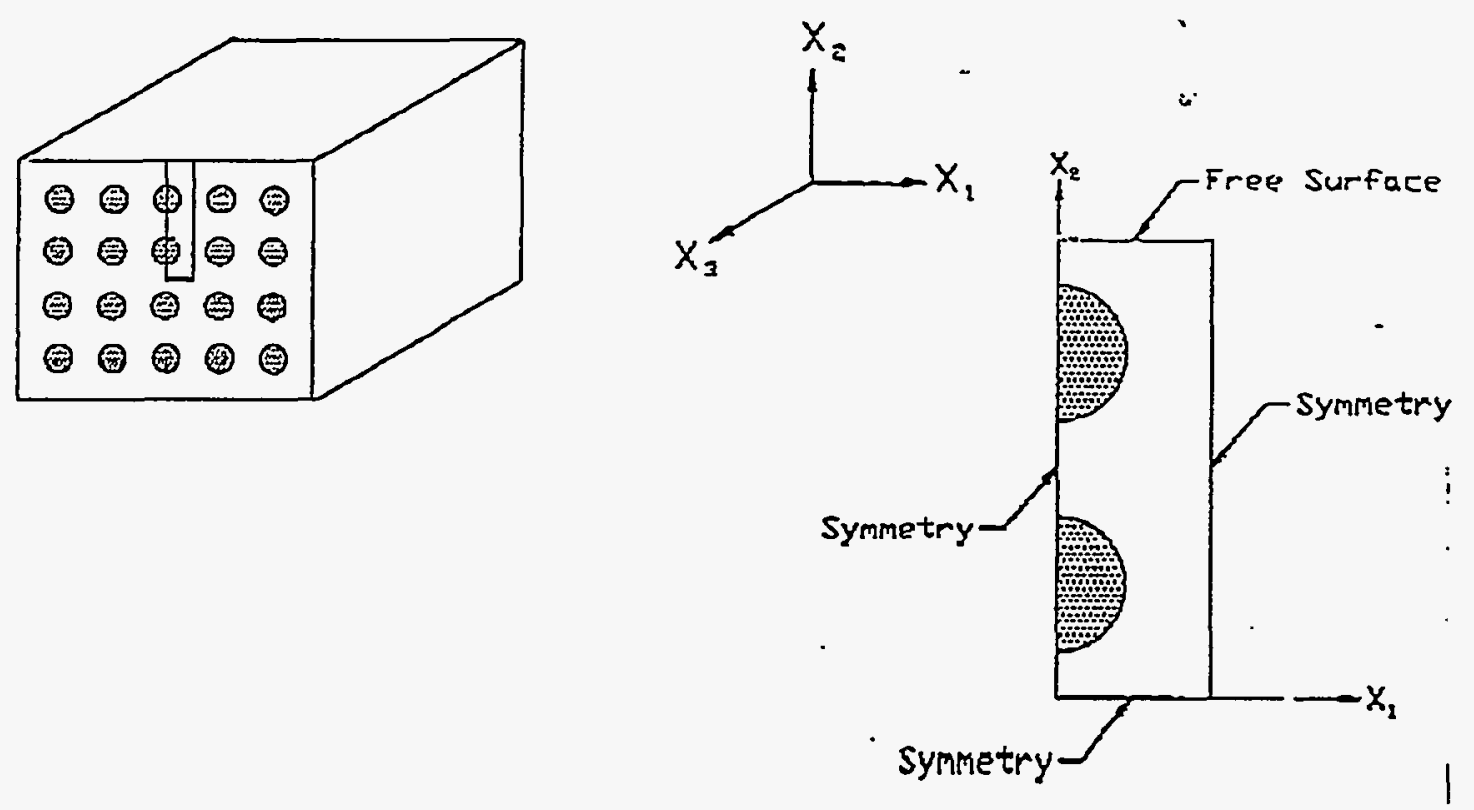

Figure 9. Depiction of Four-Ply Unidirectional Composite and Unit Cell 


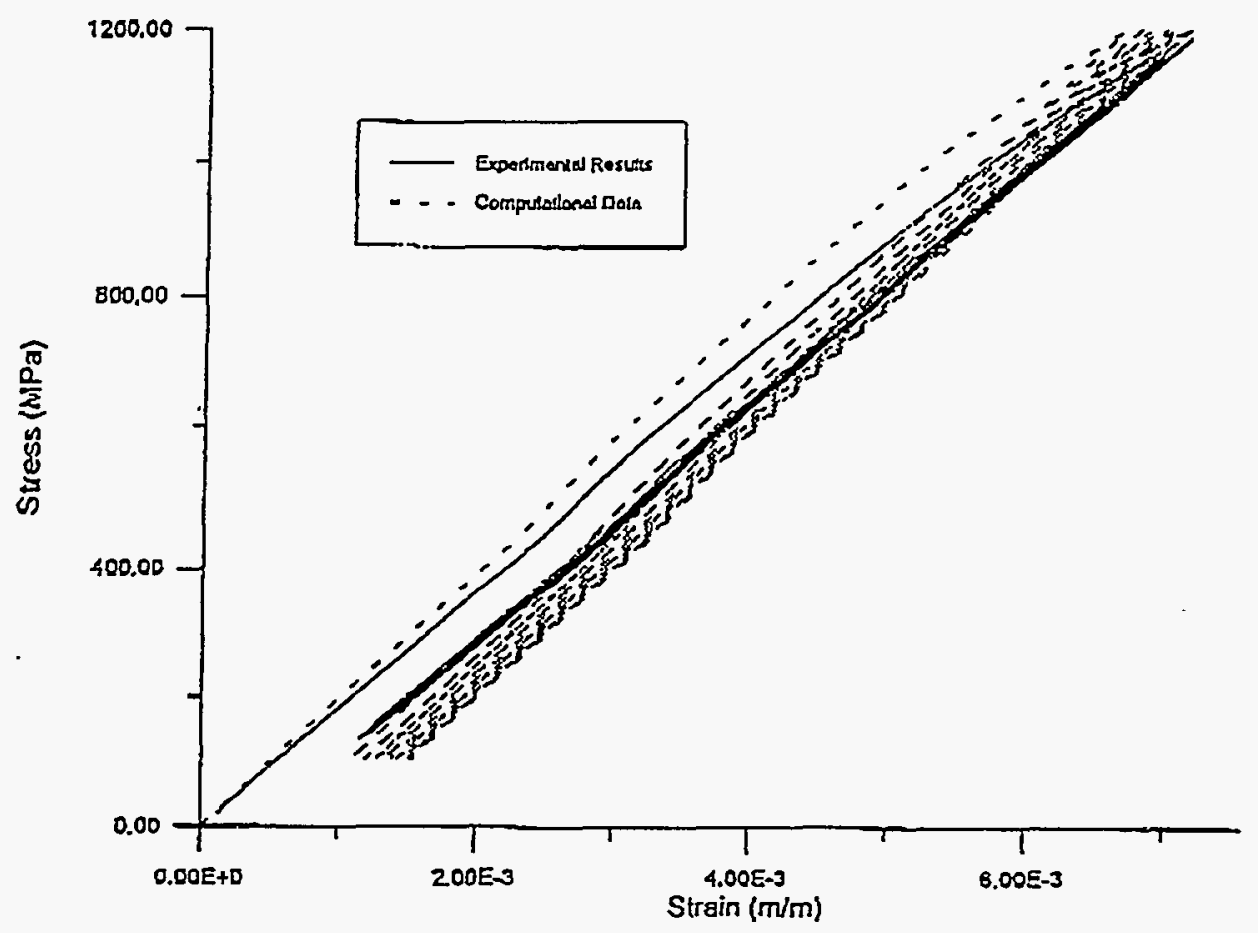

Figure 10. Comparison of Model to Unoxidized Experiment

More recently, the algorithm has been used to predict the effects of surface oxidation on the response of the composite. Although the ultimate objective of this effort is to use the algorithm to predict the effect of oxidation on life, we have not yet proceeded this far. Thus, we will report only preliminary results herein. Using the unit cell shown in Fig. 9, a plane strain analysis has been performed for a monotonically increasing displacement applied normal to the fiber direction. As shown in Fig. 11, this analysis has been performed for two cases: a specimen that is assumed to be unoxidized, and a specimen that is assumed to have been pre-oxidized with a surface oxide layer of 50 micron thickness. It is seen in the figure that the average stress-strain behavior of the composite is deteriorated in the oxidized case. The reason for this can be explained by viewing Fig- 12, wherein the crack length is plotted versus time. As can be seen, the development of surface cracks in the oxidized specimen tends to shed load to the interior of the composite, thereby causing interface debonding to occur somewhat earlier in the oxidized specimen. This effeet is demonstrated in Fig. 13, wherein the evolution of interface radial stress shows unloading as the interface crack propagates. It is our belief that this mechanism has a substantial impact on the life of the composite. Therefore, subsequent research of this nature will attempt to model the cyclic response both with and without the oxide layer (and surface cracks) included in the model. 


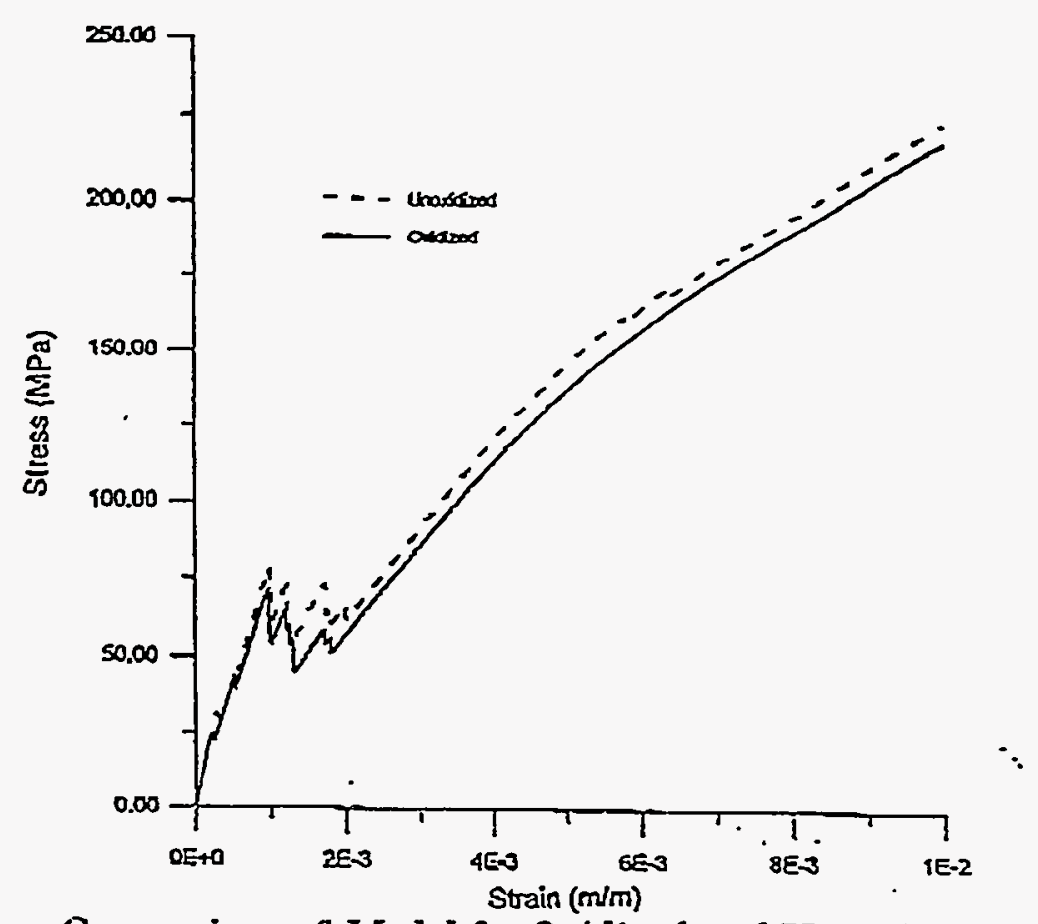

Figure 11. Comparison of Model for Oxidized and Unoxidized Cases

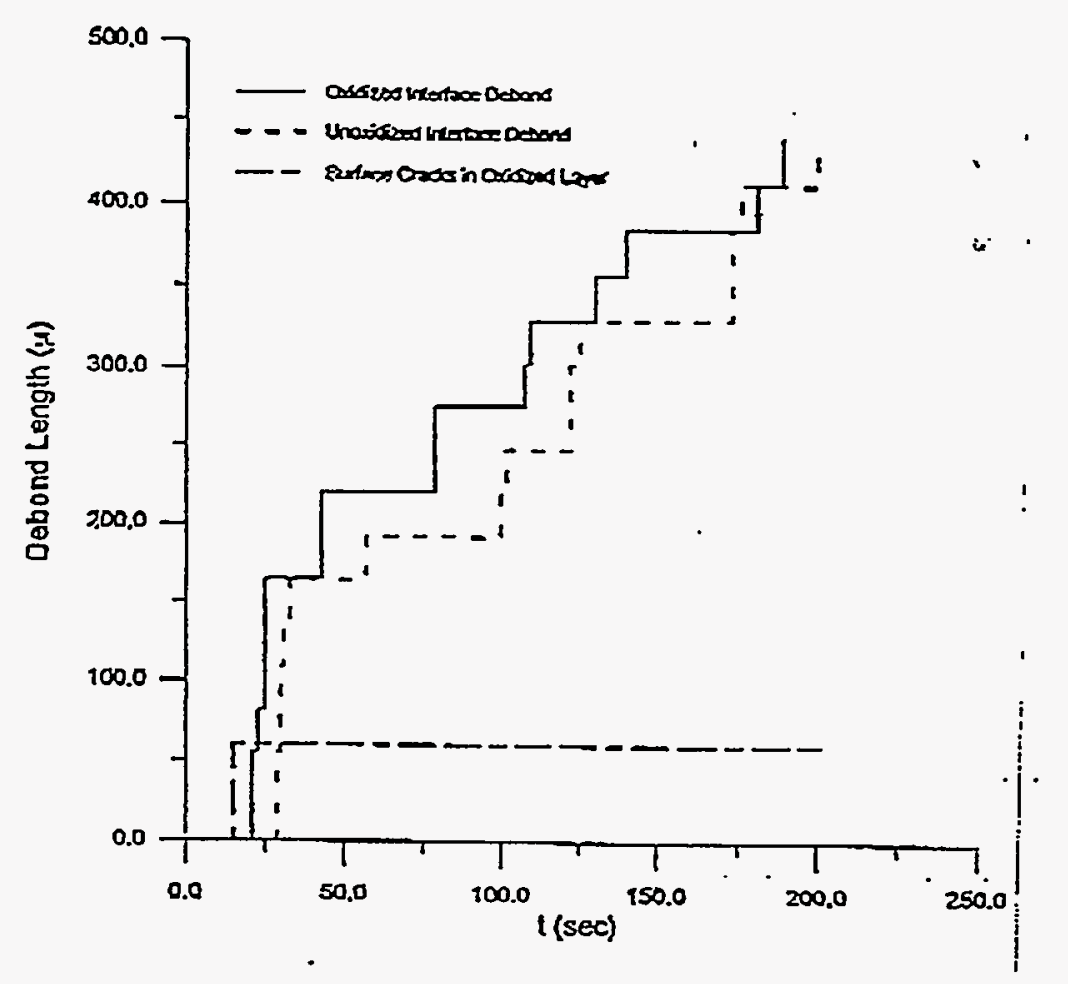

Figure 12. Predicted Crack Growth for Oxidized and Unaxidized Cases 


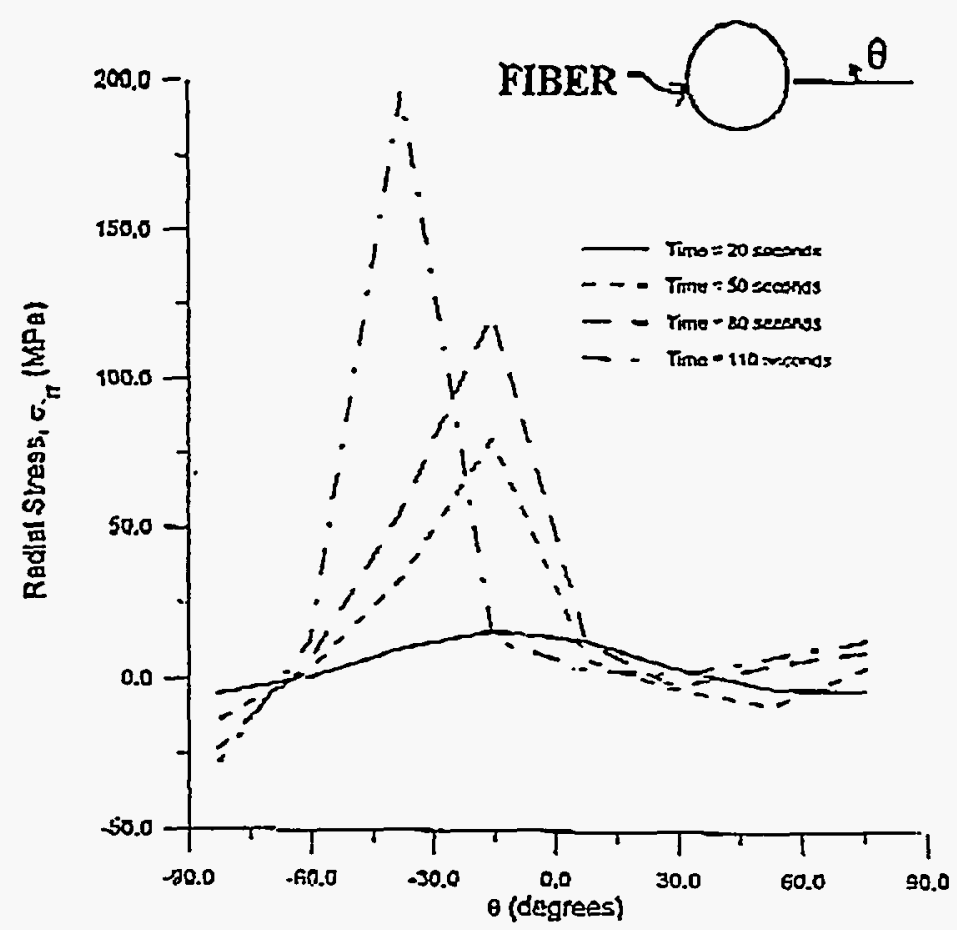

Figure 13. Predicted Evolution of Interface Radial Stress

\section{CONCLUSTONS}

The results obtained herein for an oxidized MMC suggest that a conservation of mass approach to oxygen diffusion and subsequent phase change may be appropriate for predicting the effects of damage evolution in MMC's. Furthermore, additional results reported herein for predicting cyclic fatigue response suggest that the method described in this paper may be appropriate for predicting life of MMC's. These two findings together suggest further that this approach may be useful for predicting the effect of surface oxidation on life in MMC's. The authors are currently working towards this objective.

\section{ACKNYWLEDGMENT}

The authors gratefully acknowledge the support provided for this research by the U.S. Air Force Office of Scientific Research under grant no. F49620-94-1-0341. We are also indebted to Lockheed Aerospace Corporation

- Fort Worth Division for providing the SCS6ITiß21S specimens used in the experiments. Finally, we also appreciate the experiment performed by Dr. Golam Newaz at Battelle Labs (now at Wayne State University). 


\section{REFERENCES}

[1] S. Ashley, Boeing 777 Gets a Boost from Titanium, Mech. Eng., (July 1993), pp.60-65.

[2] E.V. Zaretsky, Modeling the Future with Metal-Matrix Composites, Mach. Des., (Mar. 7, 1994), pp.124-126.

[3] J.M. Larsen, S.M. Russ, and J.W. Jones, Possibilities and Pitfalls in Aerospace Applications of Titanium Matrix Composites, in the proceedings of the NATO AGARD Conference on Characterization of Fibre Reinforced Titanium Metal Matrix Composites, Bordeaux, France, Sep. 1993.

[4] S.M. Arnold, V.K. Arya, and M.E. Melis, Reduction of Thermial Residual Stresses in Advanced Metallic Composites Based Upon a Compensation/Compliant Layer Concept, J. Compos. Mater., Vol. 26, No. 9 (1992), pp.1287-1309.

[5] J. Aboudi, Thermoelastic Response of Metal Matrix Composites with Large-Diameter Fibers Subjected to Thermal Gradients, NASA Technical Memorandum 106344 (1993).

[6] I. Doghri, S. Jansson, and F.A. Leckie, Optimization of Coating Layers in the Design of Ceramic Fiber Reinforeed Metal Matrix Composites, J. Compos. Mater., Vol. 28, No. 2 (199ł), pp.167-187.

[7] S. Jansson and F. A. Leckie, Reduction of Thermal Stresses in Continuous Fiber Reinforced Metal Matrix Composites with Interface Layers, J. Compos. Mater., Vol. 26, No. 10 (1992), pp.1474-1486.

[8] M.P. Thomas and J.E. King, Effect of Thermal and Mechanical Processing on Tensile Properties of Powder Formed 2124 Aluminum and 2124 Al-SiCp Metal Matrix Composite, Mater. Sci. Technol., (Sep. 1993), pp.742-753.

[9] A. Assar and M. Al-Nimr, Fabrication of Metal Matrix Composite by Infiltration Process: Modeling of Hydrodynamic and Thermal Behavior, J. Compos. Mater., Vol. 28, No. 15 (1994), pp.1480-1490.

[10] G.S. Jeong, D.H. Allen, and D.C. Lagoudas, Residual Stress Evolution Due to Cool Down in Viscoplastic Metal Matrix Composites, Int. J. Solids Struct., Vol. 31, No. 19 (1994), pp.2653-2677.

[11] D.B. Marshall, W.L. Morris, B.N. Cox, J. Graves, J.R. Porter, D. Kouris, and R.K. Everett, Transverse Strengths and Failure Mechanisms in TiaAl Matrix Composites, Acta Metall. Mater., Vol. 42, No. 8 (1994), pp.2657-2673. 
[12] R.H. Dauskardt, R.O. Ritchie, and B.N. Cox, Fatigue of Advanced Materials, Adv. Mater. Processes, (July 1993), pp.26-31.

[13] J.R. Ellis, M.G. Castelli, T.P. Gabb, and J. Gayda, Isothermal, Nonisothermal, and Thermomechanical Fatigue Damage/Failure Mechanisms in Titanium Matrix Composites, NASP Government Work Package 85d/e, NASA Lewis Research Center, Cleveland, Ohio, Nov. 1-3, 1993.

[14] T.P. Gabb, J. Gayda, P.A. Bartolotta, M.G. Castelli, A Review of Thermomechanical Fatigue Damage Mechanisms in Two Titanium and Titanium Alumínide Matrix Composites, Int. J. Fatigue, (Sep. 1993), pp.413422.

[15] G.M. Newaz, B.S. Majumdar, and F.W. Brust, Thermal Cycling Response of Quasi-Isotropic Metal Matrix Composites, J. Eng. Mater. Technol. Trans. ASME, (Apr. 1992), pp.156-161.

[16] J.G. Bakuckas, W.S. Johnson, and C.A. Bigelow, Fatigue Damage in Cross-Ply Titanium Metal Matrix Composites Containing Center Holes, J. Eng. Mater. Technol. Trans. ASME, Vol. 115 (Oct. 1993), pp.404-410.

[17] W.S. Johnson, Damage Development in Titanium Metal Matrix Composites Subjected to Cyclic Loading, NASA Technical Memorandum 107597 (1992).

[18] C.R. Saff, D.M. Harmon, and W.S. Johnson, Damage Initiation and Growth in Fiber-Reinforced MMC's, J. Metals, (Nov. 1988), pp:58-63.

[19] KS. Kim, A Finite Element Analysis of Crack Bridging in Metal Matrix Composites, J. Compos. Mater., Vol. 28, No. 15 (1994), pp.1413-1431.

[20] N. Fleh and E. Krempl, A Numerical Simulation of the Effects of Volume Fraction, Creep, and Thermal Cycling on the Behavior of Fibrous MetalMatrix Composites, J. Compos. Mater., Vol. 26, No. 6 (1992), pp.900-915.

[21] D. Zheng and $\mathrm{H}$. Ghonem, High Temperature/High Frequency Bridging Fatigue Crack Growth Damage Mechanisms in Titanium Metal Matrix Composites, submitted to the J. Compos. Mater., (1994).

[22] M.N. Tamin, D. Zheng, and H. Ghonem, Evolution of Bridging Fiber Stress in Titanium Metal Matrix Composites at Elevated Temperature, in the proceedings of ASTM 3rd Symposium on Advances in Fatigue Lifetime Predictive Techniques, Montreal, Quebec, Caniada, May 16-17, 1994.

[23] I.W. Hall, J.L. Lirn, and Y. Lepetitcorps, Microstructural Analysis of Isothermally Exposed Ti/SiC Metal Matrix Composites, J. Mater. Sci., (July 
15, 1992), pp.3835-3842.

[24] S. Aksoy, Stiffness Degradation in Metal Matrix Composites Caused by Thermomechanical Fatigue Loading, J. Eng. Gas Turbines Power Trans. ASME, Vol. 116 (July 19.94), pp.616-621.

[25] P.K. Gotsis, Combined Thermal and Bending Fatigue of HighTemperature Metal-Matrix Composites, NASA Technical Memorandum 104354 (1991).

[26] J. Aboudi, M.J. Pindera, and S.M. Arnold, Elastic Response of Metal Matrix Composites with Tailored Microstructures to Thermal Gradients, Int. J. Solids Struct., Vol. 31, No. 10 (1994), pp.1393-1428.

[27] M.-J. Pindera, A.D. Freed, and S.M. Arnold, Effects of Fiber and Interfacial Layer Morphologies on the Thermoplastic Response of Metal Matrix Composites, Int. J. Solids Struct., Vol. 30, No. 9 (1993), pp.1213-1238.

[28] Z.Z. Du and R.M. McMeeking, Creep Models for Metal Matrix Composites with Long Brittle Fibers, submitted to.J. Mech. Physics Solids, (1994).

[29] Z.Z. Du, R.M. McMeeking, and S. Schmauder, Transverse Yielding and Matrix Flow Past the Fibers in Metal Matrix Composites, submitted to Mech. Mater., (1994).

[30] T.E. Wilt, A Coupled/Uncoupled Deformation and Fatigue Damage Algorithm Utilizing the Finite Element Method, NASA Technical Memorandum 106526 (1994).

[31] S.M. Arnold, A Differential CDM Model for Fatigue of Unidirectional Metal Matrix Composites, NASA Technical Memorandum 105726 (1992).

[32] S.M. Arnold, Differential Continuum Damage Mechanics Models for Creep and Fatigue of Unidirectional Metal Matrix Composites, NASA Technical Memorandum 105213 (1991).

[33] D.C. Lagoudas, X. Ma, D.A Miller, and D.H. Allen, Modelling of Oxidation in Metal Matrix Composites, accepted for publication in Int. J. Eng. Sci., (1995).

[34] S. Xu, D.C. Lagoudas, and D.H. Allen, Impact of Surface Oxidation on Damage Evolution in Metal Matrix Composites, to appear in the proceedings of the ASME Winter Annual Meeting, 1995.

[35] D.C. Lagoudas, D.H. Allen, and X. Ma, Modeling of Surface Oxidation and Oxidation Induced Damage in Metal Matrix Composites, Computational 
Material Modeling, AD-Vol.42, PVP-Vol.294, A. K. Noor and A. Needleman, Eds., American Society of Mechanical Engineers, New York (1994), pp.245264.

[36] F.W. Zok, S.I. Connell, and Z.Z. Du, Fatigue Maps for Titsnium Matrix Composites, to be published in ASTM Special Technical Publication on Life Prediction Methodology for Titanium Matrix Composites (Mar. 1994).

[37] M.N. Tamin, D. Zheng, and H. Ghonem, Time-Dependent Behavior of Continuous-Fiber-Reinforced Metal Matrix Composites: Modelling and Applications, súbmitted to J. Compos. Technol. Res., (Feb. 1994).

[38] D.H. Allen, R.H. Jones, and J.G. Boyd, Micromechanical Analysis of a Continuous Fiber Metal Matrix Composite Including the Effects of Matrix Viscoplasticity and Evolving Damage, J. Mech. Physics Solids, Vol. 42, No. 3 (1994), pp.502-529.

[39] G.R. Halford, Proposed Framework for Thermomechanical Life Modeling of Metal Matrix Composites, NASA Technical Paper 3320 (1993).

[40] R.W. Neu, A Mechanistic-Based Thermomechanical Fatigue Iife Prediction Model for Metal Matrix Composites, Fatigue Fract. Eng. Mater. Struct., Vol. 16, No. 8 (1993), pp.811-828.

[41] J.L. Kroupa, R.W. Neu, T. Nicholas, D. Coker, D.D. Robertson, and S. Mall, A Comparison of Analysis Tools for Predicting the Inelastic Cyclic Response of Cross-Ply Titanium Matrix Composites, in the proceedings of the ASTM Symposium on Life Prediction Methodology for Titanium Matrix Composites, Hilton Head, South Carolina, Mar. 22-24, 1994.

[42] T. Nicholas, J. Zuiker, and J. Pernot, Characterization of Titanium Matrix Composites, NASP Technical Memorandum 1199, Vol. I (Apr. 1995).

[43] M.R. Eggleston and E. Krempl, The Transverse Creep and Tensile Behaviour of SCS-6Ai-6Al-4V Metal Matrix Composites at $482^{\circ} \mathrm{C}$, Mech. Compos. Mater. Struct., Vol. I (1994), pp.53-73.

[44] W.O. Soboyejo, Investigation of the Effects of Matris Microstructure and Interfacial Properties on the Fatigue and Fracture Behavior of a Ti-15V-3Cr3Al-3Sn/SCS9 Composite, Mater. Sci. Eng., A 183 (1994), pp.49-58.

[45] R.A. Naik, W.D. Pollock, and W.S. Johnson, Effect of a HighTemperature Cycle on the Mechanical Properties of Silicon Carbide/Titanium Metal Matrix Composites, J. Mater. Sci., (June 1, 1991), pp.2913-2920.

[46] W.C. Revelos and P.R. Smith, Effect of Environment on the Thermal 
Fatigue Response of an SCS-6/Ti-24Al-11Nb Composite, Metall. Trans., (Feb. 1993), pp.587-595.

[47] R.W. Schutz, Environmental Behavior of Beta Titanium Alloys, J. Mech., (July 1994), pp.24-29.

[48] J.V. Tesha, D.J. Stephenson, and P. Hancock, A New Criterion for Determining the Failure of Ti/SiC Metal-Matrix Composites, J. Mater. Sci., (Nov. 15, 1994), pp.5787-5793.

[49] J.J. Pernot, S. Mall, and T. Nicholas, Crack Growth Rate Behavior of a Titanium-Aluminde Alloy during Isothermal and Nonisothermal Conditions, J. Eng. Mater. Technol. Trans. ASME, (Jan. 1995), pp.118-126.

[50] D. Kouris and D. Marshall, Damage Mechanisms in TizAl Matrix Composites, J. Eng. Mater. Technol. Trans. ASME, (July 1994), pp.319-324.

[51] S.J. Connell, F.W. Zok, Z.Z. Di, and Z. Suo, On the Tensile Properties of a Fiber Reinforced Titanium Matrix Composite -- II. Influence of Notches and Holes, submitted to Acta Metall. Mater., (1994).

[52] T.B. Nguyen, S.M. Jeng, and J.M. Yang, The Effect of Fiber Orientation on Fatigue Crack Propagation in SCS-6/Ti-15-3 Composites, Mater. Sci. Eng., A183 (1994), pp.1-9.

[53] B.S. Majumdar and G.M. Newaz, Inelastic Deformation of MMC's: Thermo-Mechanical Fatigue (TMF), HITEMP Review 1993, NASA Conference Publication 19117, (1993).

[54] G.M. Newaz and B.S. Majumdar, Inelastic Deformation Mechanisms in SCS-6/Ti-15-3 MMC Lamina Under Compression, NASA Contractor Report 191170, (Sep. 1993).

[55] N. Bonora, M. Constanzi, G. Newaz, and M. Marchetti, Microdäniage Effects on the Overall Response of Long Fibre/Metal-Matrix Composites, Composites, Vol. 25, No. 7 (1994), pp.575-582.

[56] S. Mall, and B. Portner, Characterization of Fatigue Behavior in CrossPly Laminate SCS-6/Ti-15-3 Metal Matrix Composite at Elevated Temperature, J. Eng. Mater. Technol. Trans. ASME, (Oct. 1992), pp.409-415.

[57] S. Mall and P.G. Ermer, Thermal Fatigue Behavior of Unidirectional SCS-6/Ti-15-3 Metal Matrix Composite, J. Compos. Mater., Vol. 25 (Dec. 1991), pp.1668-1686.

[58] K.A. Hart and S. Mall, Thermomechanical Fatigue Behavior of a Quasi- 
Isotropic SCS6-Ti-15-3 Metal Matrix Composite, J. Eng. Mater. Technol. Trans. ASME, (Jan. 1995), pp.109-117.

[59] L.A. Wittig and D.H. Allen, Modeling the Effect of Oxidation on Damage in SiC/Ti-15-3 Metal Matrix Composites, J. Eng. Mater. Technol. Trans. ASME, Vol. 116 (July 1994), pp.421-427.

[60] L.D. Hurtado and D.H. Allen, Effect of Oxidation on Damage Evolution in Titanium Matrix MMC's", in the proceedings of the Symposium on Inelasticity and Micromechanics in Metal Matrix Composites, Twelfth U.S. National Congress of Applied Mechanics, Seattle, June 26-July 1, 1994.

[61] Timetal 21S Data Sheet, TIMET, Denver, May 1993.

[62] J.C. Fanning, Timetal 21S Property Data, unpublished TIMET Henderson Technical Lab Report, (1993).

[63] R.W. Neu, Nonisothermal Material Parameters for the Bodner-Partom Model, in the proceedings of the ASME Winter Annual Meeting, New Orieans, November 28. December 3, 1993.

[64] B. Bavarian, V. Wahi, G. Canzona, and M. Zamanzadeh, in the proceedings of the AEROMAT 93: Advanced Aerospace Materials/Process Conference, 1993.

[65] B. Bavarian, G. Canzona, and M. Zamanzadeh, in the proceedings of the CORROSION 93: NACE Annual Conference and Corrosion Show, 1993, pp.243/1-243/9.

[66] B. Bavarian and M. Zamanzadeh, in the proceedings of the CORROSION 93: NACE Anmual Conference and Corrosion Show, 1993, pp.284/1-284/10.

[67] J.S. Grauman, Corrosion Behavior of TIMETAL@21S for NonAerospace Applications, in the proceedings of the 7th World Conference on Titanium, San Diego, June 1992.

[68] J.S. Grauman and E.E. Mild, in the proceedings of the OMAE Conference, Edmonton, June 1992.

[69] W.M. Parris and P.J. Bania, Oxygen Effects on the Mechanical Properties of TIMETAL $\$ 21 \mathrm{~S}$, in the proceedings of the 7th World Conference on Titanium, San Diego, June 1992.

[70] T.A. Wallace, K.E. Wiedemann, and R.K. Clark, Osidation Characteristics of Beta-21S in Air in the Temperature Range 600 to $800^{\circ} \mathrm{C}$, NASA Technical Memorandum 104217, (1992). 
[71] P.S. Liu, K.H. Hou, W.A. Baeslack, and J. Hurley, Laser Welding of an Oxidation Resistant, Metastable-Beta . Titanium Alloy--\$-21S, in the proceedings of the 7th World Conference on Titanium, San Diego, June 1992.

[72] R.R. Cervay, SCS-6/B21S and SCS-9/B21S Mechanical Property Evaluation, NASP Contractor Report 1165, (Apr. 1994).

[73] R.R. Cervay, o/ß21S Physical and Mechanical Propcrty Evaluation, NASP Contractor Report 1169, (Sep. 1994).

[74] P.J. Bania and W.M. Parris, Çß-21S: A High Temperature Metastable Beta Titanium Alloy, in the proceedings of the Titanium 90 - Products and Applications Conference, Titanium Development Association, Dayton, Ohio, 1990.

[75] R.W. Neu and T. Nicholas, Thermomechanical Fatigue of SCS-6/Timetal 21S Under Out-of-Phase Loading, in the proceedings of the 1993 ASME Winter Annual Meeting, New Orleans, November 28 - December 3, 1993.

[76] H. Ghonem, Y. Wen, and D. Zheng, An Interactive Simulation Technique to Determine the Internal Stress States in Fiber Reinforced Metal Matrix Composites, Mater. Sci. Eng., Al77 (1994), pp.125-134.

[77] H. Ghonem, Y. Wen, and D. Zheng, Effects of Temperature and Frequency on Fatigue Crack Growth in Ti-ß21S Monolithic Laminate, Mater. Sci. Eng., Al61 (1993), pp.45-53.

[78] M.G. Castelli, Isothermal Damage and Fatigue Behavior of SCS6/Timetal 21S $[0 / 90]_{S}$ Composite at $650^{\circ} \mathrm{C}$, NASA Contractor Report 19534.5, (June 1994).

[79] M.G. Castelli, Thermomechanical Fatigie Damage/Failure Mechanisms in SCS-6/Timetal 21S [0/90]s Composite, submitted to Compos. Eng., (1994).

[80] M.G. Castelli, An Advanced Test Technique to Quantify Thermomechanical Fatigue Damage Accumulation in Composite Materials, J. Compos. Technol. Res., (Oct. 1994).

[81] R.W. Neu and I. Roman, Acoustic Emission Monitoring Damage in Metal-Matrix Composites Subjected to Thermomechanical Fatigue, Compos. Sci. Technol., Vol. 52 (1994), pp.1-8.

[82] D. Coker, N.E. Ashbaugh, and T. Nicholas, Analysis of the Thermomechanical Behavior of [0] and [0/90] SCS-6/Timetai@21S 
Composites, in the proceedings of the ASME Winter Annual Meeting, 1993.

[83] R.W. Neu, and T. Nicholas, Effect of Laminate Orientation on the Thermomechanical Fatigue Behavior of a Titanium Matrix Composite, J. Compos. Technol. Res., (July 1994), pp.214-224.

[84] G. Newaz, Evaluation and Modeling of Mechanical Response and Strength of MMC in Compression, unpublished report, (1994).

[85] R.W. Neu, D. Coker, and T. Nicholas, Cyclic Behavior of Unidirectional and Cross-Ply Titanium Matrix Composites, submitted to Int. J. Plast., (1994).

[86] T. Nicholas and S.M. Russ, Response of a [0/90] SCS-6/Timetal 21S Composite to Isothermal and Thermomechanical Fatigue, in the proceedings of the Structural Testing Technology at High Temperature -- II, the Society for Experimental Mechanics, November 1993, pp.155-164.

[87] S. Mall, D.G. Hanson, T. Nicholas, and S.M. Russ, Thermomechanical Fatigue Behavior of a Cross-Ply SCS-6/B21-S Metal Matrix Composite, in the proceedings of the ASME Winter Annual Meeting, 1992.

[88] D. Coker, R.W. Neu, and T. Nicholas, Analysis of the Thermoviscoplastic Behavior of [0/90] SCS-6/Timetal@21S Composites, in the proceedings of the Second Symposium on Thermomechanical Fatigue Behavior of Materials ASTM, Phoenix, November 14-15, 1994.

[89] R.W. Neu, Thermomechanical Fatigue Damage Mechanism Maps for Metal Matrix Composites, Thermo-Mechanical Fatigue Behavior of Materials: 2nd Volume, ASTM STP 1263, M. J. Verrilli and M. G. Castelli, Eds., American Society for Testing and Materials, Philadelphia, (1995).

[90] D.H. Allen, A Review of the Theory of Thermomechanical Coupling in Inelastic Solids, Appl. Mech. Rev., American Society of Mechanical Engineers, Vol.44, No.8 (1991), pp.361-373.

[91] KS. Chan, S.R. Bodner, and U.S. Lindholm, Phenomenolgical Modeling of Hardening and Thermal Recovery in Metals, J. Eng. Mater. Technol. Trans. ASME, (Jan. 1988), pp.1-8.

[92] L.A. Wittig, A Micromechanical Model of Oxidation Effects in SiC/Ti Metal Matrix Composites, Master's Thesis, Texas A\&M University, College Station, Texas, (1993).

[93] A. Needleman, A Continuum Model for Void Nucleation by Inclusion Debonding, J. Appl. Mech. Trans. ASME, Vol. 54 (1987), pp.525-531. 
[94] V. Tvergaard, Micromechanical Modeling of Fibre Debonding in a Metal Reinforced by Short Fibres, in the proceedings of the IUTAM Symposium on Inelastic Deformation of Composite Materials, G. J. Dvorak, Ed., SpringerVerlag, 1990, pp.99-111.

[95] V. Tvergaard and J.W. Hutchinson, The Influence of Plasticity on Mixed Mode Interface Toughness, J. Mech. Physics Solids, Vol. 41, No. 6 (1993), pp.1119-1135.

[96] D.H. Allen, M.R. Eggleston, and L.D. Hurtado, Recent Research on Damage Development in SiC/Ti Continuous Fiber Metal Matrix Composites, to appear in Fracture of Composites, E. A. Armanios, Ed., in Key Engineering Materials, Trans Tech Publications, (1995).

[97] D.C. Lo and D.H. Allen, Modeling of Delamination Damage Evolution in Laminated Composites Subjected to Low Velocity Impact, Int. J. Damage Mech., Vol. 3, No. 4 (Oct. 1994), pp.378-407.

[98] F. Costanzo and D.H. Allen, D. H., A Continuum Mechanics Approach to Some Problems in Subcritical Crack Propagation, Int. J. Fract., Vol. 63, No. 1 (1993), pp.27-57.

[99] F. Costanzo and D.H. Allen, A Continuwn Thermodynamics Analysis of Cohesive Zone Models, accepted for publication in the Int. J. Eng. Sei., (1995).

[100] D.A. Miller, Damage Evolution of a SiC/Ti-15-3 Metal Matrix Composite with Different Heat Treatments, Master's Thesis, Texas A\&M University, College Station, Texas, (1995). 


\section{Figure List}

Figure 1. Oxide thickness vs. time for various geometries with constant $c$, where $a$ is the radius of the inner surface and $b$ is the radius of the outer surface in microns for the cylindrical geometry.

Figure 2. Normal and Tangential Components of the Crack Opening Displacement in the Cohesive Zone

Figure 3. Graphical Depiction of the Function $F(\lambda)$

Figure 4. Composite Life in Argon vs. Air Environments

Figure 5. Optical photograph of fatigued specimen at $482^{\circ} \mathrm{C}$ (in Air), where the plane of view is normal to the loading direction, $X_{3}$

Figure 6. Optical photograph of fatigued specimen at $650^{\circ} \mathrm{C}$ (in Argon), where the surface transverse to the loading direction, $\mathrm{X}_{3}$, is shown

Figure 7. Average Stress vs. Strain for Cyclic Loading at $482^{\circ} \mathrm{C}$ (in Air)

Figure 8. Comparison of Oxidation Model to Experiment

Figure 9. Depiction of Four-Ply Unidirectional Composite and Unit Cell

Figure 10. Comparison of Model to Unoxidized Experiment 、

Figure 11. Comparison of Model for Oxidized and Unoxidized Cases

Figure 12. Predicted Crack Growth for Oxidized and Unoxidized Cases

Figure 13. Predicted Evolution of Interface Radial Stress 
Publication Abbreviations used (according to the Engineering Index 1993)

Acta Metall. Mater.

Adv. Mater. Processes

Appl. Mech. Rev.

Composites

Compos. Eng.

Compos. Sci. Technol.

Fatigue Fract. Eng. Mater. Struct.

Int. J. Damage Mech.

Int. J. Eng. Sci. .

Int. J. Fatigue

Int. J. Fract.

Int. J. Plast.

Int. J. Solids Struct.

J. Appl. Mech. Trans. ASME

J. Compos. Mater.

J. Compos. Technol. Res.

J. Wing. Gas Turbines Power Trans. ASME

J. Eng. Mater. Technol. Trans. ASME

J. Mater. Sci.

J. Mech.

J. Mech. Physics Solids

J. Metals

Mach. Des.

Mater. Sci. Eng.

Mater. Sci. Technol.

Mech. Eng.

Mech. Compos. Mater. Struct.

Mech. Mater.

Metall. Trans.

To appear in the praceedings of the Symposium on Recent Developments in Engineering Soience at the Socioty of Engineering Science (SES) 32nd Annual Technical Meeting, New Orleans, October 29-November 1, 1985

\section{DISCLAIMER}

report was prepared as an account of work sponsored by an agency of the United States This report was prepared as an account of work spont nor any agency thereof, nor any of their Government. Neither the United States Government nor any agency lecel liability or responsiemployees, makes any warranty, express or implied, or ans information, apparatus, product, or bility for the accuracy, completeness, or usefulness of any information, apperist rights. Referprocess disclosed, or represents that its use would not infringe pres by trade name, trademark, ence herein to any specific commercial product, process, or serte or imply its endorsement, recommanufacturer, or otherwise does not necessarily constitute or any agency thereof. The views mendation, or favoring by the United States Government or ansarily state or reflect those of the and opinions of authors expressed herein thereof. 